\title{
Venezuelan Government Disclaimer toward Humanitarian Assistance of International Communities
}

\author{
Kumajaya \\ Perguruan Tinggi IImu Kepolisian, Jakarta, Indonesia \\ kumajaya1987@gmail.com
}

\section{Rachmat Setiawan}

Perguruan Tinggi IImu Kepolisian, Jakarta, Indonesia

rrsetiawan@gmail.com

Submitted: 26 March 2019; Revised: 24 November 2019; Accepted: 27 February 2020

\begin{abstract}
Abstrak
Artikel ini membahas faktor-faktor yang menjadi alasan Venezuela dalam menolak bantuan kemanusiaan dari komunitas internasional atas tragedi kemanusiaan yang terjadi di negaranya. Kajian dalam paper ini menggunakan pendekatan konstrutivisme dalam melihat hubungan antara sense of identity dan sense of vulnerability dalam menganalisis respon Venezuela terhadap masuknya bantuan kemanusiaan internasional dari badan-badan Perserikatan Bangsa-Bangsa (PBB) ke negaranya. Hasil kajian dalam paper ini menunjukkan bahwa penolakan terhadap bantuan komunitas internasional yang dilakukan oleh pemerintah Venezuela bertujuan untuk melindungi Venezuela dari intervensi kepentingan aktor internasional.

Kata kunci: bantuan humaniter, komunitas internasional, konstruktivis, identitas, kerentanan.
\end{abstract}

\begin{abstract}
This paper discusses the factors that became the reason for Venezuela in rejecting humanitarian assistance from the international community for the humanitarian tragedy occurring in the country. This study employed a constructivist approach in looking at the relationship between sense of identity and sense of vulnerability in analyzing the Venezuelan response to the entry of international humanitarian aid from United Nations (UN) agencies into the country. The results revealed that the rejection of international community assistance by the Venezuelan government aimed to protect the country from intervening interests of international actors.

Keywords: humanitarian assistance, international community, constructivist, sense of identity, sense of vulnerability.
\end{abstract}

\section{INTRODUCTION}

One of the striking trends in the Post-Cold War is the increasing role of international aid agencies in helping victims of natural disasters, economic crises, and war. Not only decreasing the intensity of armed conflict after the end of World War, but it also made the presence of foreign aid agencies. In a war situation and significant natural disasters, the state is no longer able to provide essential services to its citizens, causing the international community to intervene in the country by giving aid. Generally, states and combatants also allow their presence, even in some cases forming safe zones and logistics lines since humanitarian organizations are usually apolitical and neutral. Thus, humanitarian assistance is a necessity to discuss (Danny, 2013).

The next challenge for humanitarianism is the increasing resistance to international assistance by local authorities. This rejection does not only occur in the cases of war but also in the event of natural disasters. In the notes of the United Nations Office for the Coordination of Humanitarian Affairs (OCHA), there was at least sixteen times rejection of the countries around the world in the case of international assistance for natural disasters from 1984 to 2013 (UN Humanitarian, 2019). 
One of the examples of the latest rejection is from Venezuela, which is facing a food and drug crisis over the past few years. Venezuela has transformed into an extraordinary country in the Latin America region, and it becomes a country having powerful ideological roots in the region, along with Bolivia and Cuba (CSIS, 2019). In addition to having a strong ideological base, this country also has abundant natural resources in the oil sector (Maulana, 2019). It is what makes Venezuela being more special compared to other Latin American countries. Furthermore, there are two countries possessing ideological similarity with Venezuela that attempts to become an alliance when western countries isolated it. Those countries are Russia and China. Russia seeks to be a close alliance of Venezuela by providing all the goods needed by Venezuela when this country is isolated by western countries (Negroponte, 2018), and China helps to defend Venezuela in various critical international forums (Nichols, 2017).

At present, a massive humanitarian crisis is taking place in Venezuela as a result of a prolonged political conflict due to the political ideology adopted by Hugo Chavez. Chavez opposed western hegemony in Venezuela because it harms the Bolivarian ideology existing in Latin America. After Chaves's death, Maduro, who later ascended the throne to become President of Venezuela, continued the political path chosen by Chavez in leading Venezuela's political government. It resulted in a lot of pressure from the west, especially in the economic aspect that ultimately made the Venezuelan community falls into humanitarian crises, where blackouts and famine occurred everywhere (Latouche, 2018).

The humanitarian disaster occurring in Venezuela is not only a domestic problem but also a regional problem in Latin America. It is because many Venezuelans have fled into refugees to neighboring countries around Venezuela that has become a problem in Latin America (Rendon \& Schneider, 2018). Even so, Venezuela remains to reject humanitarian assistance from the international community to help its civilians through the humanitarian crisis.

Somehow, the country insisted not to accept the items they needed most from several UN agencies. The weak interaction of Venezuelan cooperation and foreign relations indicates Venezuela's resistance toward international political constellation. This country seeks to find strategic partners in the world that have been dominated by the interests of Western countries. This paradigm confirms that Venezuela has a fundamental interest in rejecting the values of humanitarianism in the form of allocation of humanitarian assistance from the international community, especially in the fields of development or humanitarian assistance. Thus, it can be drawn a red thread that there are considerations in the political aspects, which are transformations of economic, social, and other fields, causing Venezuela to reject international humanitarian aids.

Based on these explanations, the author will analyze the related factors causing the Venezuelan government to close humanitarian access regularly and how the Maduro regime has remained consistent in its policy of rejecting humanitarian assistance provided by the international community.

\section{THEORETICAL FRAMEWORK}

One of the paradigms of good governance in the science of international relations, which can be the initial basis for Venezuela's choice to reject international assistance, is Constructivism. According to this paradigm, the behavior of a country is determined by intersubjective meaning, where national interests are created by the identity of that country (Adler, 1997). It is following the concept of "identity and interest structures" developed by Wendt (1992), where identity is formed because of the interests brought by the state through the learning process and the interaction processes existing within the country. Therefore, national identity could explain the rational causes of Venezuela's rejection toward assistance.

The paradigm of constructivism in international relations study is introduced by Nicholas Onuf (1989) through his seminal "World Our Making". It was later continued in 1992 by Alexander Wendt in his article "Anarchy is What States Make of It" (Rachmawati, 2012). Onuf assumed that political phenomenon is not independent, but there is always a force that has designed so that it occurs. Likewise, a reality in international relations is the result of human action. Onuf introduced the concept that actions and words, which manifest in a set 
of rules and policies, are capable of large-scale social construction.

Constructivism by Wendt focuses on social discourse and communication occurring among international actors, through the content and influence of several communications and exchange of ideas that actors do. Wendt emphasized that actors use ideas to construct relationships and material reality. Thus, ideas precede negotiations and interpret history to make relationships, either conflictual or cooperative (Asrudin \& Suryana, 2009). According to Wendt, the structure and social system contain three elements, namely material, interests, and ideas. The significance of material conditions will be influenced by interests, while ideas will affect interests. This opinion from Wendt then made an essential contribution to the development of international relations science, which places ideas before the material. Wendt assumed that the cold war ended not because America succeeded in dominating the world but the Soviets no longer looked at the west as an enemy (Rachmawati, 2012).

a) On another occasion, John Hobson mapped constructivism into three variants (Hobson, 2000): International society centric constructivism. It argues that the international community can influence national identity and interests. Norms of the international community will be transmitted to a country through international organizations. An international organization will teach a country how interests in the country are enforced.

b) State centric constructivism. Hobson pointed out that the state has full power to determine which part of the pressure of international organizations to be applied in the country and which are rejected. Therefore, it could be that if there is an international organization giving specific directions to more than one country, then each country may not necessarily receive the same, all returned to the needs of each country for the choices and directions given.

c) Radical constructivism. It debates the existence of sovereignty of the states and challenges it. It assumes that the state is the result of social construction and shows the imagination of harmony as a whole nation, whereas many domestic political interests are at odds with each other. The imagination of harmony is a sense of togetherness that tends to be forced even though they did not know each other before, those who sue this country can also be referred to as the internal other. Those who are involved in radical constructivism variants always question the form of the state and redefine what the state means.

In various organizations, including states, there is a tendency to have the nature of constructivism as mentioned above and generally enter into one of the three variants expressed by Hobson. Organizations will be included in any variant, not something happening by accident, but being planned and directed from the beginning (Fadillah, 2014).

Stewart Patrick, in his seminal, Weak Links: Fragile State, Global Threat and International Security, stated that the state tends to defend itself from various real threats or other softer forms, including the application of sanctions to isolation in international relations. Political ideology, past experiences and the character of the leaders become the most potent benchmark in bringing the direction of the state to the other mainstream opposite the dominant power or affiliation. In the era of globalization, countries emerged became new powers in international politics. For this reason, third world countries have many opportunities to develop their politics accompanied by profit-loss considerations, going forward or backward and others by minimizing weak self-confidence, which will then increase vulnerability to the sovereignty of a country (Patrict, 2011).

Preliminary observations show that Venezuela is one of the last retainers of world socialism that often criticizes capitalist countries such as the United States, which are considered to control various kinds of international institutions, including humanitarian aid agencies. This research will observe more deeply the impact of ideological identity conflict on Caracas's decision to close itself out of external assistance.

The experience becomes an essential consideration for the Venezuelan government. The spirit and values of Bolivarianism are still adopted by several countries, including Venezuela, causing dependency on capitalist 
countries to trigger problems later on. Imperialism, neo-colonialism, exploitation in natural resources is a problem that will emerge when a state declares a permissive attitude toward international humanitarian assistance.

This study employed a qualitative research method to examine and describe a phenomenon in a social context (Cassell \& Symon, 1994). The author used library research in collecting data and information about Venezuelan disclaimers on humanitarian possessiveness by international communities.

\section{RESULT AND ANALYSIS}

\section{SENSE OF IDENTITY AS THE ASSISTANCE DISCLAIMER'S FACTOR}

Principally, ideology is a collection of ideas. It can be considered a comprehensive vision as a way of looking at everything. In general, a group of ideas can be interpreted by the class dominant in all members of the community. The primary purpose behind the ideology is to offer change through the process of normative thought. Ideology is a system of abstract thought or not just the formation of ideas applied to public problems to make this concept the core of politics. Implicitly, every political thought follows an ideology even though it is not placed as an explicit system of thinking.

To do that, the Venezuelan government adopted a policy of populism in doing so. The political character of populism, which is based on the leadership of an influential figure and has the direct persuasive ability to the people, the use of popular-democratic traditions, and the politics of mobilization of the undercurrent, is inherent in the political movements of Hugo Chavez and his Bolivarian circles. Now it is experiencing a shift from Chaves to Maduro (BBC News, 2019).

It is a reflection of the differences existing between Venezuela and donor countries, the intersection between capitalism and national-socialism. Based on the constructivism paradigm, it explains that humans are the media in constructing social reality. In the case of Venezuela, President Maduro made an understanding of Bolivarianism as a manifestation of the lifestyle set of Venezuelan people during his regime.
During the 2005 World Social Forum in Porto Allegre Brazil, Hugo Chavez gave a long speech and, for the first time, proclaimed that the Bolivarian Revolution aimed not only against the design of neoliberalism but to realize the 21st Century Socialism project. In the program, Chavez emphasized that it is vital to transcend capitalism, but capitalism cannot be surpassed through the capitalist system. The project of 21st-century socialism can only surpass capitalism. However, in his speech, Chavez himself did not construct Venezuela as a state of socialism in the classical sense. Chavez's new socialism does not intend to destroy private property, but to ensure that the state through its sovereignty works based on the principle of cooperation with other nations to provide the best welfare for its people. Nowadays, many people still believe in the dream even though Chavez has died, and it was exploited by the Maduro government (BBC News, 2019).

Still, in this case, the leadership position is significant to shape the construction of social reality, because as is generally the case in third world countries such as Venezuela, leadership has a vital position to create a social order in its territory. Proven by his success, Maduro retained his power, so despite getting various attacks both from inside and outside the country, it is comparable to the anti-capitalism understanding that continues to reverberate in his country. In the case of Venezuela, even foreign companies must obtain strict supervision from the state under the pretext of national interests.

In his leadership, Maduro helped to open opportunities for international trade cooperation. Nevertheless, he continued to position himself parallel with partner countries, including the United States, China, and India, as Venezuela's massive export targets. It includes cooperation in terms of military reinforcement with Russia, in the form of arms trade and combat vehicles.

The Venezuelan government also expressed their sense of solidarity with Argentine by supporting Argentine ownership of Malvinas Island, South Georgia and the South Sandwich taken by the British Empire since 1833. Maduro made this defense because it was inspired by the struggle of Simon Bolivar, who fought to free Latin America from the grip of the United States, Europe, and other western countries. Even in the United Nations 
General Assembly, Venezuela often submitted negotiations regarding the position of several islands in Latin America, which were still under the authority of the British Empire (Negroponte, 2018).

However, Maduro thought that Venezuela was merely a political object for donor countries. There was also concern from him that undesirable influences had entered into Venezuela during the international humanitarian assistance. Furthermore, these influences jeopardize the positions of socialism, Marxism, Bolivarianism, and Chauvinism, which are the foundations of Bolivian statehood. That was what made Maduro reject various international humanitarian assistance, especially between 2013-2018.

\section{SENSE OF IDENTITY AS THE ASSISTANCE DISCLAIMER'S FACTOR}

The politicization of different subjects from donor countries is a crucial issue for donor-recipient countries. Naturally, the recipient country must follow the scheme of the donor country either directly or not. Since 2013-2018, there was a domestic political dynamics in Venezuela due to a large number of discussions on how the restructuring process was to provide an opportunity for the entry of international humanitarian assistance to Venezuela. It happened because the government was considered ineffective in overcoming the humanitarian crisis that occurred.

Since the Chavez era and now continued by Maduro, Venezuela has been adopting many closed Cuban-style economic systems and put severe pressure on private companies, even to the nationalization of hundreds of private companies. It was carried out by applying rigorous censorship of the media and silencing civil liberties. Maduro's current strength is as facility because he was once Chavez's closest crony. This power is not obtained through the results of a rigorous selection of who is the best figure for the economic progress and welfare of the Venezuelan people. Because of this political crony factor, a new social system was formed, namely people's power that emerged to fight the regime (Aljazeera, 2018).

In other words, the power obtained by Maduro was built by political collusion factors and the power structure, which then transformed into his government. It is also influenced by political closeness so that it could not accommodate various political interests existed outside of its circle.

Political problems faced by Venezuela are not only focused on political education but also have implications for international policies taken. Due to the sizeable anti-western understanding in the Maduro regime as Chavez did, Venezuela slowly made several efforts to stop cooperation with western countries by changing cooperation with countries such as Russia, China, Japan, and other countries seen as growing fertility socialism in their country.

In other words, a suggestion could be made that what is done by Venezuela is a reasonable step for a government to secure national stability and identity. It is because a country receiving much help from other countries can erode its independence, even make them depend on the assisting countries. Nevertheless, restrict the interactions with other countries cannot be assumed as a hundred percent correct action. However, a country becomes secure not by imposing restrictions on its foreign policy, but by extending to which it can produce all its needs independently (Kassab, 2017).

It is common knowledge that there are efforts from western countries to change the system that has been in force in Venezuela. Even the Western media has acknowledged that the US has long interfered in Venezuela's internal affairs by funding the opposition. The US National Endowment for Democracy (NED) website also recognizes broad interference in every aspect of Venezuela's internal politics with funds directed at various programs, including facilitating humanitarian assistance, enhancing democratic governance in Venezuela, empowering leadership and socio-political participation, campaigning for citizen participation and freedom of expression, campaigning democratic governance, and various other programs (Ariyanti, 2019).

Capitalism is an economic system where the private sector controls trade, so the profits accumulate by trading falls into the private actor's wealth. The Venezuelan government assumes that such a system will cause many problems for the domestic economy in the future. Therefore it must be directed so that the state controls the current trading system.

Thus, the existence of Maduro's repudiation of various forms of humanitarian assistance from the international community is his effort to prevent the entry of 
international actors, which will damage the internal structure of Venezuela that has been built so far. There are some examples of countries that were finally successfully entered by international actors, which ultimately complicate their country's development efforts based on state ideals. These became Maduro's consideration.

The international community has indeed provided stimulus and direction for Venezuela to change some of its domestic policies. However, the Venezuelan government is too strong to be able to take for granted any directives given by the international community. Venezuelan government belongs to the category of State Centric Constructivism, which becomes defensive when an international community comes to influence its policies. Not only receives selectively, but the Venezuelan government also refuses the international donor.

The rejection was made to minimize the potential damage to the domestic political situation, as well as to maintain the stability of the Venezuelan internal government. In other words, the Venezuelan government argued that an international actor prepared to subvert Maduro's power by hitching a ride on international aid. If it happens, it will potentially cause more considerable turmoil within the Venezuelan state, even though its main aim is to improve the Venezuelan system of government by providing political education, not by overthrowing power. Especially with the loss of a figure like Maduro that will make the capitalist system develop rapidly in Venezuela. It is the reason why Maduro rejected international assistance from 2013-2018.

\section{CONCLUSION}

In the logic of constructivism, the status of Venezuela as a country experiencing a great crisis is a situation created by western countries to be able to control Venezuela's ideology for its government's practice by aid intervention. As for, the rejection of the Venezuelan government toward humanitarian assistance is a construction of social reality that was deliberately built to avoid the grip of western hegemony within their government. At the time, the international community tried to build a discourse that the humanitarian assistance they provided could reduce the suffering of Venezuelans as a result of the incompetence of Maduro's government. The Venezuelan government built another reality that it could survive without international assistance.

Survivability is indeed an important issue for the Venezuelan government under the leadership of Nicolas Maduro. After the end of the leadership of Hugo Chaves, who succeeded in leading this country since 1999, Venezuela still faces various social, economic, and political issues. Even though the Chaves figure and the succession toward Maduro are so popular among the grassroots, many for the upper-middle class are questioning various Venezuelan domestic and foreign policies not running optimally and rationally, even the right groups consider Maduro's various policies since April 2013 has not been able to bring real progress in the social, economic or political fields.

Therefore, if it is associated with a factor of sense of identity, foreign aid is seen by Nicolas Maduro as having differences in ideological aspects. Since the leadership of Hugo Chaves, who later transformed into the era of Nicolas Maduro, Venezuela has developed as a socialist-liberal republic. Although, in terms of trade, the United States still occupies the first position of Venezuelan export-import, it does not mean that ideological factors can bring these two countries closer. It is the reason for Nicolas Maduro to reject foreign aid and humanitarianism in Venezuela around 2013-2018.

Then the next factor behind the Venezuelan government's refusal of foreign aid and humanitarianism in this country is because of the influence of the sense of vulnerability factor, that is, the potential for politicization, where the Venezuelan national transparency index is still not sufficient. In other words, even though Venezuela has gone through a long series of socio-political histories, but changes and reforms have been going on since the leadership of Chaves and Maduro. The next factor is the potential for intervention by international actors who are feared to implement prerequisites, such as other South Asian and Latin American countries, which then triggered the delegation of regime and leadership in Venezuela. It explains why Nicolas Maduro rejected foreign aid and humanitarianism in Venezuela in 2013-2018. 


\section{REFERENCE}

Aljazeera. (2018). Venezuela Crisis: Explaining From Begining. Retrieved from Aljazeera News: https://www.aljazeera .com/indepth/features/2017/04/venezuela-happen ing-170412114045595.html

Ariyanti, H. (2019, March 15). Menelisik bukti keterlibatan AS dalam upaya penggulingan rezim di Venezuela. Merdeka News. Retrieved from https://www.merdeka.com/dunia/me nelisik-bukti-keterlibatan-as-dalam-upaya-penggulingan -rezim-di-venezuela.html

Asrudin, \& Suryana, M. J. (2009). Refleksi teori hubungan internasional dari tradisional ke kontemporer. Yogyakarta: Graha Ilmu.

BBC News. (2019). Krisis Venezuela: mengapa saya tetap setia kepada Nicolas Maduro. Retrieved from https://www .bbc.com/indonesia/dunia-47492186

Cassell, C., \& Symon, G. (1994). Qualitative Methods in Organizational Research. London: Sage Publications.

CSIS. (2019). The future of Venezuela initiative (FVI). Retrieved from https://www.csis.org/programs/americas-program/ven ezuela?gclid=EAlalQobChMI8dLYofu_4gIVh9lkCh1_ZAPX EAAYAyAAEglb2PD_BwE

Danny, C. (2013). Why is humanitarian aid rejected? Comparing the motives of autocratic and democratic states. (p. p.118). New York: ECPR General Conference.

Fadillah, D. (2014). Strategi komunikasi pembentukan budaya organisasi. Humanika, 14(1). doi:10.21831/hum.v14i1.3327

Hobson, J. (2000). The state and international relations. Cambridge: Cambridge University Press.

Kassab, H. S. (2017). State and Power Vulnerability. In Prioritization Theory and Defensive Foreign Policy (pp. 59-78). Palgrave Macmillan, Cham. doi:10.1007/978-3-319-48018-3_3

Latouche, M. A. (2018, May 24). Venezuela is now a dictatorship. The Conversation. Retrieved from http://theconversa tion.com/venezuela-is-now-a-dictatorship-96960

Maulana, V. (2019, January 30). Maduro: minyak, alasan AS campur tangan di Venezuela. Sindo News. Retrieved from https://international.sindonews.com/read/1374784/42/ma duro-minyak-alasan-as-campur-tangan-di-venezue la-1548841190

Negroponte, D. V. (2018, June 19). Russian Interrest on Venezuela: A New Cold War. American Quarterly. Retrieved from https://www.americasquarterly.org/content/russian-in terests-venezuela-new-cold-war

Nichols, M. (2017, November 13). Russia, China, Others Boycott U.S. Meeting at U.N. on Venezuela. Reuters. Retrieved from https://www.reuters.com/article/us-venezuela-politics-un/ russia-china-others-boycott-u-s-meeting-at-u-n-on-venezue la-idUSKBN1DE056

Patrict, S. (2011). Weak Links: Fragile State, Global Threat and International Security. New York: Oxford University Press.

Rachmawati, I. (2012). Konstruktivisme sebagai pendekatan alternatif dalam hubungan internasional. Paradigma: Jurnal Masalah Sosial, Politik Dan Kebijakan, 16(1), 25-34. doi:10.31315/paradigma.v16i1.2456

Rendon, M., \& Schneider, M. L. (2018). Venezuela's humanitarian crisis has become a regional crisis. Center for Strategic and International Studies. Retrieved from https://csis-prod.s3 .amazonaws.com/s3fs-public/publication/180627_Ren don_VenezuelasCrisis.pdf

UN Humanitarian. (2019). Venezuelan families plant seeds of hope. Retrieved from https://unocha.exposure.co/venezue lan-families-plant-seeds-of-hope? source $=$ share-unocha 